\title{
WPŁYW INSTRUMENTÓW WSPÓLNEJ POLITYKI ROLNEJ NA GOSPODARSTWA INDYWIDUALNE W WOJEWÓDZTWIE OPOLSKIM W OPINII ROLNIKÓW
}

\section{IMPACT OF THE COMMON AGRICULTURAL POLICY INSTRUMENTS ON INDIVIDUAL FARMS IN THE OPOLSKIE VOIVODSHIP IN FARMERS' OPINION}

\author{
Jolanta KLUBA \\ Ośrodek „Pamięć i Przyszłość” \\ ul. Grabiszyńska 184, 53-235 Wrocław \\ jolanta.kluba@zajezdnia.org
}

\begin{abstract}
Zarys treści: Celem artykułu jest ocena wpływu instrumentów Wspólnej Polityki Rolnej na indywidualne gospodarstwa rolne w województwie opolskim, dokonana na podstawie badania przeprowadzonego wśród rolników. Badanie miało określić społeczno-ekonomiczne przemiany, jakie w opinii rolników zaszły na opolskiej wsi po wejściu Polski do Unii Europejskiej. Wzięło w nim udział 383 kierowników indywidualnych gospodarstw rolnych o powierzchni od 2 do 30 ha. Uzyskane wyniki ukazują m.in. wpływ unijnych regulacji na sytuację opolskich rolników, ale także stosunek do nich samych zainteresowanych. Rolnicy doceniają unijne wsparcie, jednak koncentrują uwagę głównie na dopłatach bezpośrednich i związanym z nimi wzrostem dochodów. Rzadko korzystają z innych form wsparcia, jak np. szkoleń i doradztwa. Niezbyt często również wnioskują o środki na modernizację gospodarstw, zwłaszcza jeśli mają gospodarstwa niewielkie obszarowo.
\end{abstract}

Słowa kluczowe: indywidualne gospodarstwa rolne, gospodarstwa rodzinne, dopłaty bezpośrednie, WPR, województwo opolskie.

\section{Wprowadzenie}

Wstąpieniu Polski do Unii Europejskiej i objęciu polskiego rolnictwa zasadami Wspólnej Polityki Rolnej towarzyszyły skrajnie różne prognozy. Z jednej strony wielu fachowców, w tym także reprezentantów świata nauki, postrzegało to wydarzenie jako wielką szansę, ogromnej wagi projekt cywilizacyjny, który pozwoli wsi i rolnictwu odbudować ich potencjał rozwojowy (Poczta i Hardt 2005, s. 115). Z drugiej strony sami rolnicy mieli mnóstwo obaw, związanych głównie z trudnościami w sprostaniu wymogom unijnego wspólnego rynku oraz spodziewanym wykupem polskiej ziemi. Dzisiaj wiemy już, że dekada obecności Polski w Unii Europejskiej wcale nie zmieniła na wsi aż tak wiele, jak oczekiwano (zob. np. Bukraba-Rylska 2014), co widoczne jest zwłaszcza w sytuacji małych i średnich gospo- 
darstw rolnych. Obawy rolników dotyczące integracji nie znalazły odbicia w rzeczywistości poakcesyjnej, zaś sami rolnicy również znacznie zmienili nastawienie do samej Unii Europejskiej, WPR oraz jej mechanizmów i instrumentów, z których najbardziej znanymi i najlepiej ocenianymi pozostają te o charakterze „socjalnym”, czyli dopłaty bezpośrednie (Marks-Bielska 2009, s. 135-136) i renty strukturalne (Halamska 2007, s. 11; Bułkowska i Chmurzyńska 2007, s. 15). Tymczasem wsparcie to jest wielokierunkowe i obejmuje instrumenty o szerokim i zróżnicowanym oddziaływaniu (Łopaciuk 2011, s. 8-9):

1) bezpośrednio podtrzymujące dochody rolników w postaci płatności bezpośrednich,

2) regulujące podaż produktów rolno-spożywczych poprzez wprowadzanie limitów produkcyjnych (kwoty produkcyjne) na wybrane produkty rolne oraz system odłogowania gruntów,

3) wspierające rynek wewnętrzny oraz podtrzymujące ceny, interwencję rynkową, prywatne przechowalnictwo, system cen rynkowych, a także dopłaty do produkcji, przetwórstwa i konsumpcji,

4) chroniące rynek wewnętrzny dzięki odpowiedniej polityce importowej, w której skład wchodzą m.in.: cła importowe, ceny wejścia, kontyngenty ilościowe, klauzule zabezpieczające, opłaty wyrównawcze itp.,

5) zapewniające konkurencyjność na rynku globalnym poprzez subsydia oraz opłaty eksportowe.

W niniejszym artykule przedstawiono wyniki badania zrealizowanego w 2012 r. na obszarach wiejskich województwa opolskiego, na podstawie których podjęto próbę scharakteryzowania najważniejszych przemian, jakie według badanych zaszły na obszarach wiejskich pod wpływem wspomnianych wyżej instrumentów WPR. Badanie zrealizowano w ramach ćwiczeń terenowych studentów socjologii Uniwersytetu Wrocławskiego. Objęto nim obszary wiejskie sześciu wylosowanych powiatów: opolskiego, kluczborskiego, krapkowickiego, prudnickiego, strzeleckiego i namysłowskiego. Arbitralność doboru próby oznacza, że nie jest ona reprezentatywna dla populacji wszystkich indywidualnych gospodarstw rolnych województwa opolskiego, ale dla gospodarstw o powierzchni od 2 do 30 ha. Nie jest też reprezentatywna dla poszczególnych wyodrębnionych na potrzeby analizy kategorii obszarowych (dobór nie był doborem kwotowym). Do badań został wykorzystany kwestionariusz wywiadu realizowany z kierownikami badanych gospodarstw rolnych. Analizie poddano ostatecznie 383 wywiady kwestionariuszowe. Dla uzyskania pełnego obrazu zjawiska wykorzystano również dane zastane.

Istotną częścią badania było zagadnienie wpływu WPR na polskie - w tym regionalne, opolskie - rolnictwo. Jednym z możliwych podejść w tej ocenie jest badanie opinii beneficjentów o przydatności przyjętych rozwiązań (Sokołowska i Bisaga, s. 60). W związku z tym zapytano opolskich rolników o następujące kwestie:

- korzystanie z unijnego wsparcia w różnych formach,

- przeznaczenie (kierunki wydatkowania) pozyskanych środków unijnych,

- znajomość oraz ocenę różnorodnych form wsparcia.

Ta subiektywna ocena unijnego wsparcia, czy szerzej - skutków wprowadzenia unijnych regulacji, w dużej mierze zależy od ogólnej kondycji społeczno-ekonomicznej gospodarstwa, na którą wpływ mają także inne (a nie tylko WPR) czynniki. Z tego też powodu interpretacja i analiza wyników badań została uzupełniona dostępnymi danymi z innych badań. 


\section{Rolnictwo województwa opolskiego}

Rolnictwo województwa opolskiego od wielu lat charakteryzuje się wysokimi wskaźnikami wydajności. Wysokie są plony zbóż. Region znajduje się również w czołówce pod względem rocznego udoju mleka oraz w produkcji żywca rzeźnego. Dane PSR 2010 wskazują, że w ciągu ostatnich lat zmniejszyła się hodowla (zjawisko to jest tłumaczone utrzymującymi się od wielu lat niskimi cenami skupu), natomiast powierzchnia zasiewów uległa nieznacznemu zwiększeniu. Zarazem wskazuje się na zmianę ich struktury (zmniejszenie powierzchni uprawy zbóż, ziemniaków i buraków cukrowych przy jednoczesnym wzroście powierzchni upraw rzepaku i rzepiku). Produktywność rolnictwa województwa opolskiego jest relatywnie dobra, o blisko 20\% wyższa niż średnia dla Polski. Porównanie jej jednak z produktywnością innych działów gospodarki nie napawa już takim optymizmem - jest znacznie niższa, co świadczy pośrednio o występowaniu na opolskiej wsi zjawiska ukrytego bezrobocia. Niewątpliwie niekorzystną cechą opolskiego rolnictwa jest rozdrobnienie gospodarstw rolnych (chociaż średni obszar gospodarstwa to wg danych PSR 2010 ok. 11 ha) oraz niewielkie wykorzystanie zakładów przetwórstwa rolno-spożywczego (opolscy rolnicy korzystają z zakładów przetwórczych z województw sąsiadujących). Problem występuje też ze zbytem produkcji rolnej.

Według wyników PSR 2010 w regionie jest ok. 45 tys. gospodarstw rolnych o średniej wielkości 11,6 ha użytków rolnych. W porównaniu z danymi z poprzedniego spisu zauważyć należy znaczące zmniejszenie liczby gospodarstw (spadek wynosi blisko 40\%), przy jednoczesnym zwiększeniu ich powierzchni (wg danych PSR 2002 średnia powierzchnia gospodarstwa wynosiła 7,6 ha użytków rolnych). Wzrost średniej powierzchni gospodarstw nie świadczy jednak o korzystnym kierunku przemian w strukturze agrarnej. Wręcz przeciwnie - w porównaniu z rokiem 2002 obserwujemy w województwie opolskim większe rozdrobnienie gospodarstw, zaś spadek liczebności dotyczy przede wszystkim tych mniejszych obszarowo (do 20 ha).

Wśród gospodarstw domowych na wsi występuje relatywnie wysoki odsetek takich, które nie użytkują gospodarstw rolnych (PSR 2002, s. 29-30). W rolniczej części wsi natomiast jest dużo gospodarstw produkujących na rynek, przy czym są to gospodarstwa duże, kierowane przez osoby z wykształceniem wyższym w stosunku do pozostałych mieszkańców wsi. Zatem, mimo że zdecydowana większość opolskich gospodarstw to gospodarstwa małe, występują również nowoczesne, duże gospodarstwa. Tzw. Ziemie Odzyskane stanowią dziś region, w którym średni obszar gospodarstwa jest relatywnie wysoki (PSR 2002, s. 55-57), o czym przesądziły głównie czynniki natury historycznej.

Pracujący w rolnictwie to $12,4 \%$ ogółu pracujących w województwie opolskim. W sektorze rolniczym pracuje więcej kobiet niż mężczyzn. Dochody z pracy we własnym gospodarstwie rolnym to wyłączne lub główne źródło utrzymania dla 18,8\% ludności wiejskiej, dla kolejnych 13,8\% jest to źródło dodatkowe. Natomiast spośród tych, dla których wskazane dochody stanowią dodatkowe źródło, większość utrzymuje się głównie z pracy najemnej (49,9\%) oraz ze źródeł niezarobkowych (42,3\%), wśród których najczęstsze to emerytury: pracownicza $(17,6 \%)$ i rolna (10,6\%). Dla 7,7\% gospodarstw utrzymujących się dodatkowo z pracy we własnym gospodarstwie, głównym źródłem utrzymania jest praca na własny rachunek. Łącznie, na podstawie danych spisowych, ze źródeł innych niż dochody z pracy $\mathrm{w}$ rolnictwie utrzymywało się w województwie opolskim (lub było utrzymywanych) 81,1 tys. osób (50,7\%) ludności związanej z gospodarstwami indywidualnymi powyżej 1 ha. 
Wyniki spisu pokazują m.in., że przeciętnie na 1 indywidualne gospodarstwo rolne przypada jedna osoba, która pracuje głównie lub wyłącznie w rolnictwie i wskaźnik ten wzrasta wraz ze wzrostem powierzchni użytków rolnych gospodarstw prowadzących działalność rolniczą. Tych jest jednak niewiele - na gospodarstwa indywidualne przypada ich ok. 1,5\%.

Spośród 28,5 tys. gospodarstw rolnych o powierzchni powyżej 1 ha użytków rolnych 99,2\% (28,2 tys.) stanowiły gospodarstwa indywidualne (w kraju - 99,7\%). W województwie opolskim, podobnie jak w kraju, dominowały gospodarstwa sektora prywatnego. W porównaniu z wynikami PSR 2002 liczba gospodarstw rolnych ogółem zmniejszyła się o 29,3 tys., tj. o 39,5\% (w kraju - o 22,4\%), a w porównaniu z uogólnionymi danymi uzyskanymi w badaniu struktury w 2007 r. - o 16,6 tys., tj. o 27\% (w kraju o 11,7\%). Największą dynamikę spadku odnotowano w przypadku gospodarstw obszarowo najmniejszych, np. liczba gospodarstw o powierzchni 1-2 ha zmniejszyła się o 56\%.

Spośród wszystkich gospodarstw działalność rolniczą prowadziło 82,1\%. W tej liczbie 98,7\% posiadało użytki rolne, 59,7\% utrzymywało zwierzęta gospodarskie. Powierzchnię pod zasiewami posiadało 82,2\% prowadzących działalność rolniczą. Najpopularniejsze uprawy to przede wszystkim zboża (76,1\% gospodarstw wskazało na ich produkcję; nieco więcej niż w kraju - dla Polski odsetek ten wynosi 68,6\%). Trzodę chlewną utrzymywało $28,1 \%$ gospodarstw rolnych, bydło niecałe $20 \%$, zaś ponad $45 \%$ drób kurzy. Największy odsetek gospodarstw prowadzących działalność rolniczą wystąpił w powiecie brzeskim (93,2\%), oleskim (91,9\%) i kluczborskim (90,6\%), najmniejszy w mieście Opolu i powiecie strzeleckim (odpowiednio: 62,6\% i 66,2\%).

Według danych ostatniego spisu rolnego 21,2 tys. gospodarstw jest wyposażonych w ciągniki (57,6\% gospodarstw prowadzących działalność rolniczą; w kraju odsetek ten wynosi 53,7\%). Udział gospodarstw, które posiadają ciągniki w ogólnej liczbie gospodarstw prowadzących działalność rolniczą jest różny w zależności od powierzchni i wynosi od 12,8\% w gospodarstwach o powierzchni do 1 ha do 97,4\% w gospodarstwach o powierzchni w przedziale 30-50 ha. Najwięcej gospodarstw z ciągnikami odnotowano w grupie obszarowej 1-5 ha i 5-10 ha (odpowiednio: 27,5\% i 23,8\% gospodarstw wyposażonych w ciągniki), a najmniej - do 1 ha (5,3\%). Co ciekawe, w porównaniu z rokiem 2002 liczba ciągników w opolskich gospodarstwach jest mniejsza o 6\%, podczas gdy w Polsce wskaźnik ten wzrósł o blisko 10\%. W przypadku gospodarstw opolskich spadek ten najbardziej zauważalny był w grupie gospodarstw najmniejszych obszarowo.

Wyposażenie gospodarstw w ciągniki jest relatywnie dobre. Średnio na jedno gospodarstwo prowadzące działalność rolniczą i posiadające ciągniki przypadało 1,8 szt. ciągników (podczas gdy w kraju - 1,4 szt.). Omawiany wskaźnik należał do najwyższych w kraju (podobny wynik uzyskały także województwa warmińsko-mazurskie oraz kujawsko-pomorskie) i wahał się w przedziale od 1,1 szt. w gospodarstwach o powierzchni 1-5 ha do 4,6 szt. w gospodarstwach największych (50 ha i więcej).

Opolskie rolnictwo jest dobrze wyposażone również w inne maszyny i urządzenia rolnicze. Łącznie według danych spisowych posiadało je 18,8 tys. gospodarstw, zaś ich liczba wyniosła 177,5 tys. Gospodarstwa posiadające maszyny i urządzenia rolnicze stanowiły ponad połowę $(50,9 \%)$ gospodarstw prowadzących działalność rolniczą. W kraju odsetek ten był niższy i wyniósł 47,6\%.

Wykorzystując funkcjonujące w literaturze przedmiotu typologie polskiego rolnictwa, dokonano poniżej oceny rolnictwa woj. opolskiego w różnych jego aspektach (Sokołowska i in. 2006 s. 53-60). 
Opierając się na typologii dotyczącej oceny wykorzystania potencjału produkcyjnego rolnictwa w różnych regionach Polski opracowanej w Instytucie Uprawy, Nawożenia i Gleboznawstwa w Puławach, województwo opolskie znajduje się - wraz z dolnośląskim - w grupie pierwszej gospodarstw (spośród pięciu wyodrębnionych). Charakterystyka rolnictwa tej grupy obejmuje wskazania na najwyższe plony zbóż, bardzo niską obsadę bydła i związaną z tym niską produkcją mleka. Wysokie plony zbóż to m.in. efekt relatywnie wysokiego poziomu nawożenia.

Inna typologia, opracowana przez zespół badaczy pod kierunkiem W. Poczty (2012) bazująca na skonstruowanym syntetycznym mierniku rozwoju, uwzględnia takie elementy, jak: przeciętna powierzchnia gospodarstwa, wskaźnik jakości rolniczej przestrzeni produkcyjnej, udział zmeliorowanych użytków rolnych, powierzchnia UR na 1 zatrudnionego, środki trwałe brutto na 1 ha UR, zużycie pośrednie na 1 ha UR, nakłady inwestycyjne na 1 ha UR, środki trwałe brutto na 1 zatrudnionego, pogłowie trzody chlewnej na 100 ha UR, pogłowie bydła na 1 ha UR. Zastosowanie tego miernika pozwoliło wyodrębnić cztery grupy typologiczne województw. Województwo opolskie należy do pierwszej z nich, cechującej się największym zasobem produkcyjnym przypadającym na 1 ha UR. Związane jest to z większą niż przeciętna w Polsce powierzchnią gospodarstw, wyższą wartością środków trwałych brutto na 1 ha UR, dobrym technicznym uzbrojeniem pracy oraz dużym udziałem zmeliorowanych UR w ogólnej powierzchni, dużym zużyciem środków obrotowych na 1 ha UR i dużą obsadą trzody chlewnej na 100 ha UR.

Z kolei w typologii K. Hanusik i S. Sokołowskiej (Hanusik i in. 2005) województwo opolskie znalazło się w grupie gospodarstw o bardzo dobrych warunkach produkcyjnych oraz dobrym stopniu wykorzystania tychże.

Jedną z bardziej znanych jest typologia przyjęta i wykorzystywana przez MRiRW, opracowana przez badaczy z Instytutu Geografii i Przestrzennego Zagospodarowania PAN oraz Instytutu Ekonomiki Rolnictwa i Gospodarki Żywnościowej. Oparto na niej m.in. Narodowy Plan Rozwoju. Wyróżniono tutaj trzy makroregiony, w nich zaś pięć regionów o dość wyraźnej specyfice. Opolskie znalazło się w Makroregionie II Północno-Zachodnim, czyli „regionie o dominacji wielkoobszarowych gospodarstw rolnych, wymagających pilnego uporządkowania własnościowych aspektów struktury agrarnej oraz koncepcji rozwoju gospodarstwa adekwatnej do wyzwań tego regionu. Nieuporządkowana własność, umowy dzierżawne nieobligujące do zachowania równowagi ekologicznej w rolnictwie, niedoinwestowane gospodarstwa wielkoobszarowe, rozpowszechniona monokultura zbożowa - prowadzą rolnictwo tego makroregionu do upadku" (Sokołowska i in. 2006, s. 59-60).

\section{Charakterystyka badanych gospodarstw}

W badaniu brano pod uwagę gospodarstwa o wielkości obszarowej od 2 do 30 ha. Literatura przedmiotu, zwłaszcza ekonomiczna, podkreśla, że coraz więcej gospodarstw powyżej 30 ha to gospodarstwa, które łatwiej mogą sprostać oczekiwaniom gospodarki rynkowej (ze względu na skalę produkcji). J. Zegar (2009, s. 259, 264) wskazuje, że współcześnie gospodarstwa o obszarze co najmniej 30 ha są dopiero w stanie zapewnić utrzymanie rodziny właściciela z dochodów uzyskiwanych z tych gospodarstw. Do tych gospodarstw trafia też większość środków unijnych (zarówno w postaci dopłat bezpośrednich, jak i tych o charakterze funduszy celowych). 
Ponadto dla procesu kształtowania struktury agrarnej kluczowe miejsce zajmują gospodarstwa średnie (10-30 ha). Jest to bowiem kategoria obszarowa obejmująca takie gospodarstwa, które będą ulegać albo rozdrobnieniu (sprzedaż ziemi lub dzierżawa), albo koncentracji i - co za tym idzie - przechodzić do wyższych grup obszarowych. Dla badań własnych przyjęto zatem obszar 30 ha jako maksymalny, jako że takie gospodarstwa mają szansę przekształcić się w samowystarczalne. Określenie wielkości minimalnej na poziomie 2 ha użytków rolnych wynika z faktu, że dopiero członkowie gospodarstw o takiej wielkości obszarowej mogą rejestrować się jako bezrobotni oraz korzystać z wszystkich instrumentów wsparcia. Do tego warto zaznaczyć, że - pomijając działy specjalne produkcji rolnej - praktycznie żadne gospodarstwo o wielkości obszarowej poniżej 2 ha nie jest w stanie utrzymać się z dochodów z tego gospodarstwa uzyskiwanych, tym bardziej zaś pozbawione jest szans na rozwój.

Tabela 1. Struktura obszarowa badanych gospodarstw $(n=383)$

\begin{tabular}{|l|c|c|}
\hline \multicolumn{1}{|c|}{ Wielkość gospodarstwa w ha } & Liczba gospodarstw & $\%$ \\
\hline $2-5$ & 59 & 9,1 \\
$5,1-7$ & 33 & 8,6 \\
$7,1-10$ & 47 & 12,3 \\
$10,1-15$ & 58 & 15,1 \\
$15,1-20$ & 59 & 15,4 \\
$20,1-25$ & 42 & 11,0 \\
$25,1-30$ & 85 & 22,2 \\
\hline Razem & 383 & 100,0 \\
\hline
\end{tabular}

Źródło: opracowanie własne.

W próbie przeważały gospodarstwa obszarowo większe. 25,3\% z nich prowadziło w momencie badania produkcję specjalistyczną, w tym ok. 75\% taką, która jest objęta dopłatami unijnymi. Najczęściej dotyczyła ona produkcji mleka. Badane gospodarstwa były gospodarstwami rodzinnymi. Ich obecni kierownicy w większości przypadków w czasie prowadzenia gospodarstwa rolnego zmieniali jego obszar. Ponad połowa z nich powiększała gospodarstwo, niecałe 14\% dokonało pomniejszenia użytkowanego gospodarstwa. Nieco więcej niż 1/3 badanych nie dokonywała żadnych zmian obszarowych. Najbardziej stabilne pod względem przemian obszarowych pozostają gospodarstwa średniej wielkości. Wśród respondentów (kierowników gospodarstw rolnych) przeważali mężczyźni (ok. 70\%), w zdecydowanej większości w wieku produkcyjnym (tab. 2).

Największy odsetek badanych legitymował się wykształceniem zasadniczym zawodowym (głównie nierolniczym), najmniejszy - wykształceniem policealnym i licencjackim. Niewiele było osób z wykształceniem wyższym. Struktura wykształcenia badanych w dużym stopniu zbieżna jest ze strukturą wykształcenia ludności wiejskiej województwa opolskiego, które od lat zajmuje ostatnie miejsca w rankingu województw pod względem poziomu wykształcenia ludności. 
Tabela 2. Struktura respondentów wg płci i wieku w \% ( $n=383)$

\begin{tabular}{|l|c|c|c|}
\hline \multirow{2}{*}{\multicolumn{1}{|c|}{ Wiek }} & \multicolumn{2}{|c|}{ Płeć } & \multirow{2}{*}{ Ogółem } \\
\cline { 2 - 3 } & kobiety & mężczyźni & 14,1 \\
\hline Poniżej 25 lat & 9,0 & 19,9 & 27,2 \\
$26-35$ & 51,4 & 17,3 & 43,1 \\
$36-55$ & 13,5 & 55,1 & 7,0 \\
56-65 & 1,8 & 9,2 & 8,6 \\
Powyżej 65 lat & 24,3 & 2,2 & 100,0 \\
\hline Razem & 100,0 & 100,0 & \\
\hline
\end{tabular}

Źródło: opracowanie własne.

\section{Wpływ unijnych dotacji na sytuację indywidualnych gospodarstw rolnych}

W zrealizowanych badaniach istotne było pytanie: czy wstąpienie Polski do UE wpłynęło w jakikolwiek sposób na sytuację ludności wiejskiej związanej z rolnictwem. Zdecydowana większość badanych (ponad 90\%) uważała, że tak. Podobnie większość uznała, że wpływ ten ma pozytywny wydźwięk; jedynie kilka osób (9) wskazało, że zmiana, jaka zaszła na polskiej wsi po akcesji, ma charakter negatywny. Argumentując swoje stanowisko, wskazywali oni na rozrost biurokracji, narzucane limity produkcji (i kary za ich przekroczenie) oraz wymogi, które trudno spełnić. Wśród osób określających wpływ unijnych regulacji jako pozytywny przeważały wskazania na poprawę kondycji ekonomicznej gospodarstw (wyższe dochody). Wskazane przez badanych zarówno wady, jak i zalety akcesji, nie odbiegają zasadniczo od tych, jakie wskazują rolnicy w ogólnopolskich sondażach (zob. np. 10 lat członkostwa..., s. 8-9, 11).

Interesujące było również, czy rolnicy opolscy korzystają z unijnych dotacji. Przede wszystkim istotny jest w tym kontekście fakt wnioskowania o wsparcie unijne. Większość badanych (ponad 80\%) wskazała, że nie wnioskowała o wsparcie unijne. Takie odpowiedzi są zaskakujące, ponieważ m.in. wysoki udział płatności obszarowych wskazuje, że odsetek wnioskujących o wsparcie ze środków z UE jest jednak nieco wyższy. Dane z Agencji Restrukturyzacji i Modernizacji Rolnictwa (www.arimr.pl dostęp: 17.07.2014) pokazują, że wnioski o płatności obszarowe w województwie opolskim składa rokrocznie ok. 27500 indywidualnych gospodarstw rolnych, co stanowi ponad $60 \%$ wszystkich gospodarstw rolnych regionu, a odsetek ten jest jeszcze większy, jeśli nie odniesiemy tej liczby do gospodarstw poniżej 1 ha (jako że i tak nie mają one możliwości otrzymania dopłat, a takich gospodarstw również nie było w zrealizowanej próbie badawczej).

W efekcie należy uznać, że rolnicy nie traktują dopłat bezpośrednich jako wsparcia, o które się wnioskuje (mimo iż formalna procedura związana z ich otrzymaniem obejmuje m.in. złożenie wniosku), a jako takie uznają tylko to wsparcie, które wiąże się z inwestycjami, modernizacją, zakupami nowych maszyn itp. Można stwierdzić, że badani dopłaty uznają po prostu za dochód uzyskiwany z gospodarstwa rolnego. Przemawia też za tym fakt, że wskazując alternatywne źródła dochodów, nie podawali zasadniczo dopłat unijnych. Popularność, powszechność tych dopłat być może powoduje, że nie są one uznawane za szczególną formę wsparcia i dlatego też badani rolnicy nie wspominają 
o wnioskowaniu o nie. Warto również zaznaczyć, że na tę popularność wpływ może mieć ich charakter. Płatności bezpośrednie są wydatkowane przez rolników w zależności od ich bieżących potrzeb (taka jest zresztą ich rola); nie mają - w przeciwieństwie do innych form wsparcia - charakteru dotacji celowych, których przeznaczenie (i efekty wydatkowania) jest kontrolowane i ściśle określone. Wniosek o dopłaty bezpośrednie zawiera wprawdzie pewne deklaracje (np. co do upraw) i mogą one zostać skontrolowane, jest to jednak zupełnie inna sytuacja niż rozliczanie dotacji otrzymanej na modernizację gospodarstwa. Dopłaty bezpośrednie są postrzegane jako podstawowa korzyść z akcesji (zob. także Kutkowska i in. 2015; Sokołowska i Szwiec 2011), co w omawianych badaniach kierownicy gospodarstw rolnych również podkreślali uznając, że w ostatnich latach zanotowali wzrost dochodów.

Odpowiadając, dlaczego nie składali wniosków o dofinansowanie, badani rolnicy podkreślali dwie sprawy. Po pierwsze wskazywali na trudności w przygotowaniu odpowiednich dokumentów, po drugie na problemy w rozliczaniu dotacji. Często powoływano się na przykład sąsiada, mieszkańca sąsiedniej wsi, który wprawdzie otrzymał środki, ale miał problem z rozliczeniem przyznanej dotacji. O takich sytuacjach i ich skutkach pisze także A. Krzyworzeka (2014, s. 208-212).

Wśród ankietowanych, którzy odpowiedzieli, że składali wnioski o wsparcie, najwięcej było osób starających się o środki na modernizację gospodarstwa rolnego oraz dopłaty do produkcji specjalistycznej. Niecałe $10 \%$ wnioskujących starało się o możliwość dofinansowania do rozpoczęcia pozarolniczej działalności gospodarczej. Blisko 90\% wnioskujących o jakiekolwiek wsparcie otrzymało je.

Spośród odsetka osób, które otrzymały dotacje w ramach różnych programów, zdecydowana większość wydała te środki na zakup maszyny, urządzenia do gospodarstwa (42\%) lub opłacenie bieżącej produkcji rolnej (47\%), ponadto na powiększenie gospodarstwa i remont w obejściu. Zdarzały się jednak sytuacje, że pieniądze te były wydatkowane na bieżącą konsumpcję, przy czym były to pojedyncze wskazania (ok. 3\% wszystkich, którzy otrzymali wsparcie). Kierunek wydatkowania tych środków wynika z przepisów dotyczących rozporządzania nimi - szczególnego znaczenia przepisy te nabierają w przypadku środków otrzymywanych w postaci jednorazowego transferu o określonym przeznaczeniu (np. modernizacja gospodarstwa lub dopłaty do produkcji specjalistycznej). Uznanie za kwalifikowalne wydatków ze środków unijnych obwarowane jest kontrolą (w zakresie zgodności realnych wydatków z założonymi we wniosku) i w większości przypadków możliwości wydatkowania środków niezgodnie z przeznaczeniem właściwie nie istnieją.

Taka struktura wydatkowania środków unijnych, podyktowana w znacznym stopniu przepisami warunkującymi ich otrzymanie, powoduje, że to właśnie maszyny i urządzenia w gospodarstwach rolnych (majątek produkcyjny) są tą częścią majątku trwałego, która podlega unowocześnieniu (Poczta 2012, s. 70). Modernizacja gospodarstw rolnych jest bowiem, zgodnie z logiką unijną, rozumiana bardzo szeroko i znakomicie wpisują się w nią takie inwestycje, które są najłatwiejsze do zrealizowania (zakup maszyn), a które jednocześnie w ocenie samych rolników świadczą o nowoczesności (nowe maszyny i urządzenia do produkcji rolniczej). Zarazem warto w tym miejscu zauważyć, że w przeciwieństwie do tych środków dopłaty bezpośrednie są przeznaczane przeważnie na bieżącą konsumpcję.

Około 85\% badanych zamierza w kolejnych latach wnioskować o unijne wsparcie przeznaczone dla rolnictwa. Wśród osób, które na pytanie o zamiar wnioskowania w najbliższych latach o dotacje odpowiedziały negatywnie, przeważały takie, które wskazywały, 
że ograniczeniem w ich przypadku jest wiek (zwykle nie tyle formalnym, co psychicznym). Zaledwie kilka wskazań obejmowało odpowiedzi odnoszące się do nieznajomości zasad wnioskowania lub zniechęcenia wcześniejszymi niepowodzeniami.

B. Fedyszak-Radziejowska (2012, s. 110) twierdzi, że z unijnego wsparcia „korzystają głównie gospodarstwa większe, co sprzyja modernizacji polskiego rolnictwa oraz poprawie jego efektywności". Uzyskane w badaniu wyniki pokazują, że sytuacja - przynajmniej w odniesieniu do opolskich gospodarstw rolnych o powierzchni 2-30 ha - ma się trochę inaczej. Z unijnego wsparcia korzystają przede wszystkim osoby użytkujące gospodarstwa większe, ale zależność ta nie jest prosta (ryc. 1). W opisywanych badaniach widać wyraźnie, że o wsparcie wnioskują przede wszystkim młodsi wiekiem użytkownicy. Wiązać się to może z faktem, że jego pozyskanie wymaga wypełnienia wniosku, co z kolei warunkowane jest umiejętnością jego wypełnienia, a często powoduje konieczność wizyty w ośrodku doradztwa lub skorzystania z pomocy specjalisty. Wprawdzie po kilku latach rolnicy już dość dobrze radzą sobie z wnioskami, ciągle jednak część z nich unika wszelkich biurokratycznych formalności, w tym także tych związanych ze wsparciem unijnym. O tym, że składane przez rolników wnioski są przygotowane poprawnie, świadczy skuteczność uzyskiwania tego wsparcia (w badaniach - ponad 90\%, podobnie wg danych Agencji Restrukturyzacji i Modernizacji Rolnictwa - od ok. 70\% w przypadku wniosków o środki na modernizację gospodarstw do ponad 90\% w przypadku wniosków o płatności bezpośrednie) ${ }^{1}$.

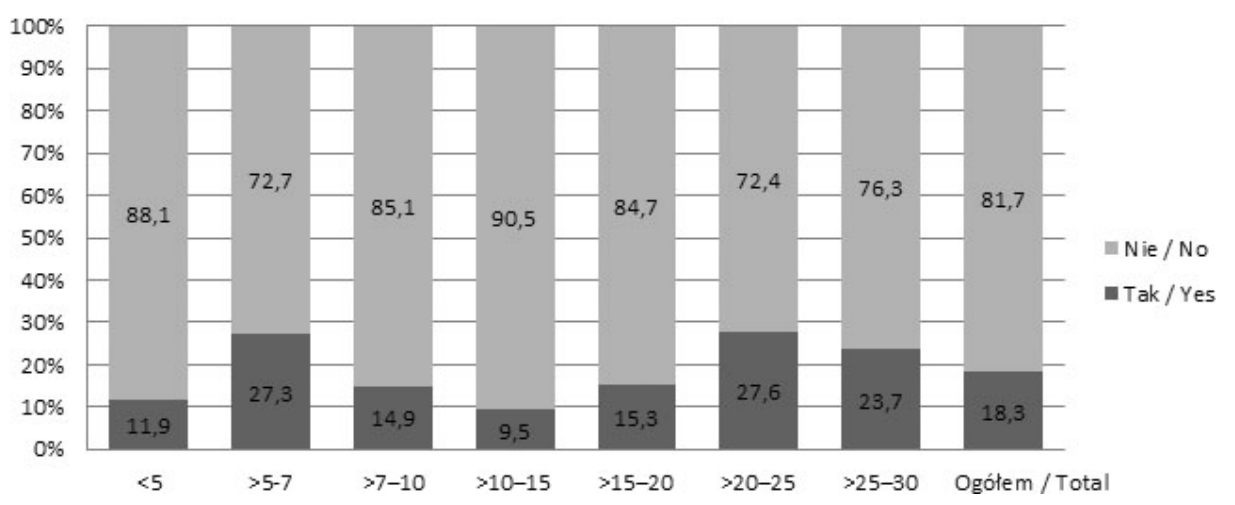

Ryc. 1. Wnioskowanie o wsparcie z UE według wielkości użytkowanego gospodarstwa $(n=383)$ Application for the EU support according to farm size $(n=383)$ Źródło/Source: badania własne/own research.

Najczęściej o wsparcie unijne wnioskują osoby o średnim stażu gospodarowania. Najmniejszy odsetek wnioskujących w ramach kategorii wiekowej występuje wśród osób, które gospodarują samodzielnie powyżej 40 lat (ryc. 2). Potwierdza to, że osoby starsze nie starają się o pozyskanie środków z UE. Warto przy tym zauważyć, że obok często wskazywanego motywu braku umiejętności wypełniania wniosków, respondenci ci uznawali, że im się już nie opłaca, że są za starzy. Korzystania (i zamiaru korzystania) z unijnego wsparcia nie różnicują takie zmienne, jak płeć badanych czy ich wykształcenie. Poza wiekiem badanych właściwie żadna z cech demograficzno-społecznych nie odgrywa tutaj większej roli.

${ }^{1}$ Dane dotyczą ostatnich trzech pełnych lat, tj. 2010-2013, www.arimr.pl 


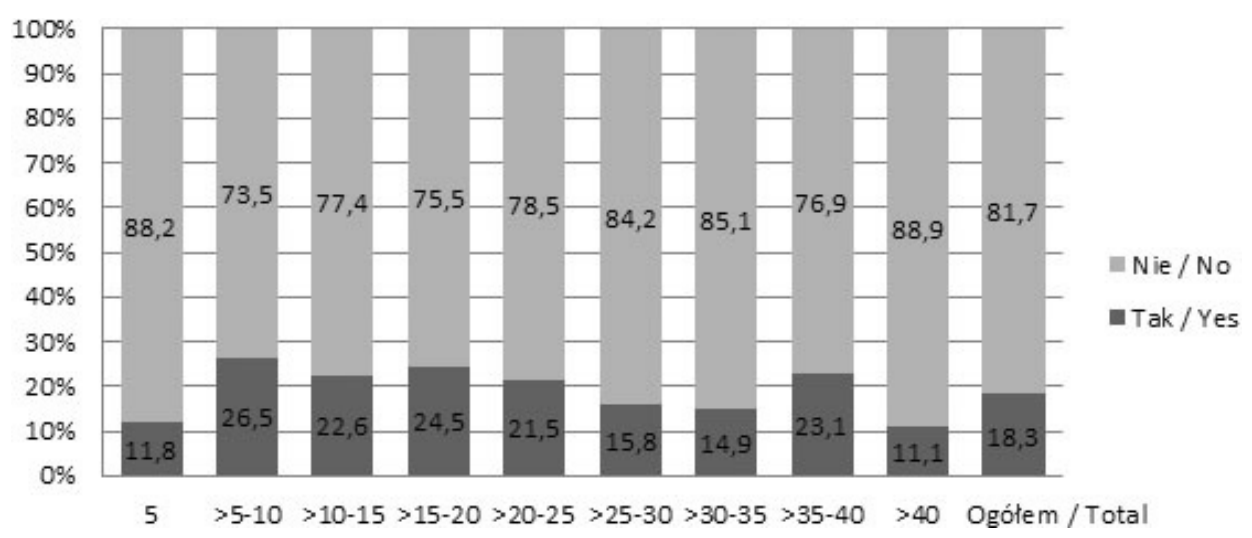

Ryc. 2. Wnioskowanie o wsparcie z UE według lat gospodarowania w gospodarstwie rolnym $(n=378)$ Application for the EU support according to the number of years in managing farm Źródło/Source: badania własne/own research.

B. Fedyszak-Radziejowska (2012, s. 110) wskazuje, że istnieje także powiązanie pomiędzy korzystaniem z unijnych dotacji a związkami gospodarstw rolnych z rynkiem. Zależność tę charakteryzuje w następujący sposób: „Rolnicy wytwarzający żywność głównie na samozaopatrzenie są w znacznie mniejszym stopniu beneficjentami WPR niż gospodarstwa towarowe. Co nie oznacza, że produkcja na własne potrzeby jest wśród beneficjentów PROW zupełnie nieobecna". Scharakteryzowany powyżej związek jest widoczny również w przypadku opolskich rolników. Warto jednak pamiętać, że związki z rynkiem mają głównie gospodarstwa duże, trudno zatem wskazać, który z tych dwóch czynników ma znaczenie decydujące.

\section{Znajomość i ocena działań szkoleniowych}

W analizach dotyczących wpływu WPR na obszary wiejskie często wspomina się o istnieniu, lecz dużo mniej mówi się o skutkach wdrażania programów mających na celu realizowanie szkoleń i doradztwa dla rolników. Zdecydowana większość tych szkoleń skierowana jest na uzyskiwanie przez rolników „nierolniczych” kompetencji, które mają za zadanie przede wszystkim przygotować rolników do prowadzenia innej niż gospodarowanie na roli działalności. Przystępując do badań, dokonano przeglądu oferty szkoleniowej na Opolszczyźnie. Niestety wcześniejsza konstatacja była jak najbardziej zasadna: szkoleń, które pozwoliłyby rolnikom nabyć bądź poprawić, umocnić posiadane umiejętności w zakresie działalności rolniczej, było bardzo mało. Rolników zapytano w związku z tym przede wszystkim o to, czy w ogóle słyszeli o jakichkolwiek szkoleniach, które są skierowane do nich, a współfinansowane ze środków UE. Nie podawano przy tym konkretnych zagadnień, nazw ani zakresów tematycznych.

Zdecydowana większość badanych rolników słyszała o szkoleniach unijnych skierowanych do przedstawicieli ich zawodu (265 osób, tj. 69,2\% respondentów); aż 81,1\% spośród tych, co słyszeli, deklaruje, że wie, czego szkolenia te dotyczą (ryc. 3). Obserwacja nie jest zaskakująca. Z uwagi na unijne wymogi dotyczące promocji projektów realizowanych z unijnych środków (a także kwoty środków na tę promocję przeznaczanych) trudno jest nie spotkać się z ogłoszeniem, informacją o szkoleniu finansowanym ze środków UE. Ogło- 
szeń takich bardzo dużo jest przekazywanych zarówno poprzez reklamę w mediach (prasa, radio, tv), jak i inne formy reklamy (ulotki, plakaty, bilbordy). Nieco częściej znajomość szkoleń finansowanych ze środków unijnych „ze słyszenia” deklarowali mężczyźni (83\%) niż kobiety (78\%), jednak bardziej niż płeć odpowiedzi badanych w tym zakresie różnicowało wykształcenie.

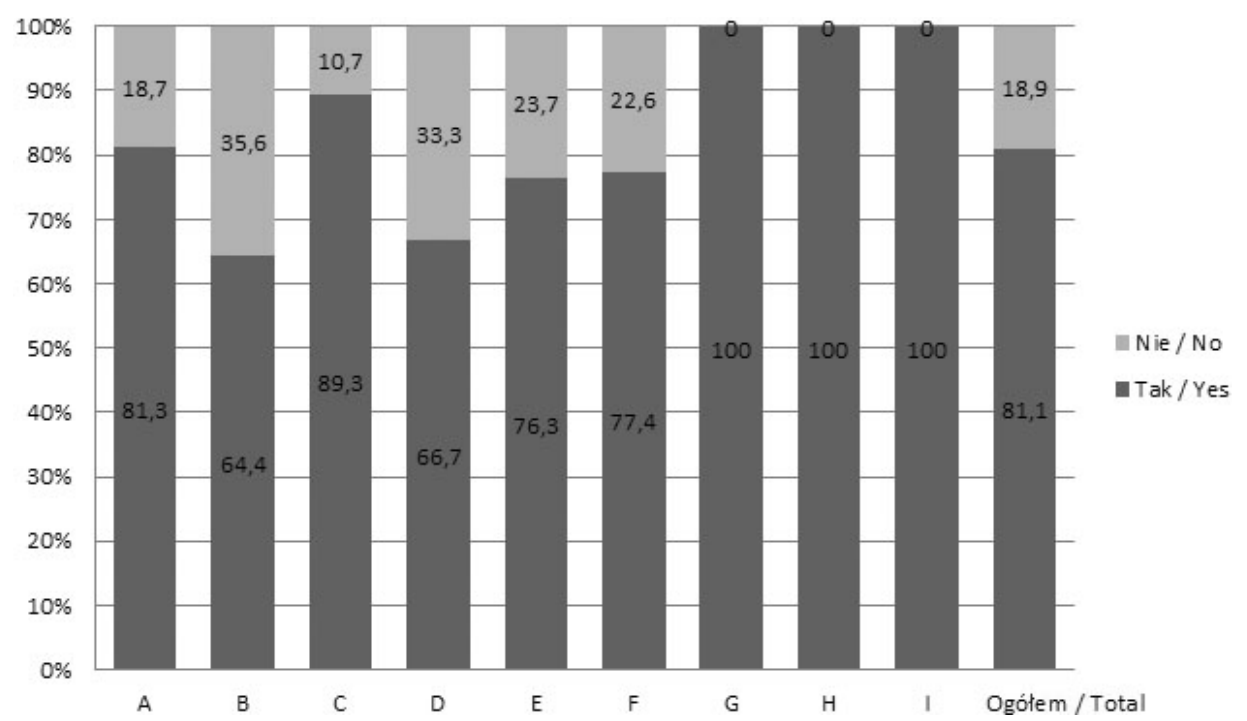

Ryc. 3. Znajomość szkoleń współfinansowanych ze środków UE według wykształcenia $(n=265)^{*}$ Knowledge of training co-funded by the EU by education level A - Podstawowe/Primary B - Zasadnicze zawodowe rolnicze/Agricultural vocational C - Zasadnicze zawodowe nierolnicze/Non-agricultural vocational D - Średnie ogólnokształcące/Secondary E - Średnie zawodowe rolnicze/Agricultural secondary F - Średnie zawodowe nierolnicze/Non-agricultural secondary G - Policealne nierolnicze/Non-agricultural post-secondary $\mathrm{H}$ - Wyższe rolnicze/Agricultural tertiary I - Wyższe nierolnicze/ Non-agricultural tertiary

Źródło/Source: badania własne/own research.

Biorąc pod uwagę powyższe charakterystyki można stwierdzić, że częściej - chociaż różnica nie jest duża - deklarują znajomość tematyki (zagadnień) szkoleń dofinansowanych z UE osoby z wykształceniem wyższym i średnim. Generalnie zachodzi zależność, że wraz ze wzrostem wykształcenia respondenci częściej wskazują na znajomość tematyki szkoleń do nich kierowanych. Jeśli porównamy odsetki osób z danym wykształceniem w próbie z odsetkami deklarującymi znajomość szkoleń z UE zauważymy, że w 100\% znajomość tę wskazują osoby z wykształceniem wyższym (bez względu na profil), w ok. 80\% osoby z wykształceniem podstawowym, w ponad $50 \%$ osoby z wykształceniem policealnym nierolniczym, średnim zawodowym rolniczym oraz zasadniczym zawodowym nierolniczym. Znajomość tematyki szkoleń wskazał też stosunkowo duży odsetek osób z wykształceniem podstawowym oraz zasadniczym zawodowym nierolniczym (ryc. 3). Zdecydowanie lepszą orientację w unijnych szkoleniach deklarują ponadto osoby młodsze.

Deklaratywna znajomość zakresu i tematyki szkoleń nie znajduje do końca przełożenia na znajomość faktyczną. Według respondentów szkolenia te dotyczą przede wszystkim:

- nauki pisania wniosków,

- nauki obsługi nowych urządzeń, 
- przekwalifikowania na inny zawód,

- ogólnie - wiedzy przydatnej młodym rolnikom,

- rozpoczęcia pozarolniczej działalności gospodarczej.

O ile podany wyżej zakres zagadnień nie świadczy najgorzej o znajomości tematów szkoleń skierowanych do rolników przez samych zainteresowanych, o tyle warto zaznaczyć, że spośród tych, którzy uznali, że wiedzą, czego szkolenia dofinansowane z UE dotyczą, blisko połowa udzielała przy tym pytaniu odpowiedzi typu: „nooo... takie tam ogólne” lub wprost: „tak dokładnie to ja tam nie wiem”.

Odpowiedzi na pytanie o to, co dają szkolenia dofinansowane z UE, skierowane do rolników, można podzielić na dwie podstawowe grupy. W pierwszej znajdą się te, które odnoszą się do faktycznych umiejętności, kwalifikacji itp. Natomiast w drugiej takie, które pokazują, że dla udzielających odpowiedzi respondentów szkolenia te nie przedstawiają większej wartości. Do pierwszej kategorii zaliczyć należy następujące odpowiedzi:

- wiedzę nową/dodatkową,

- nowe doświadczenia za darmo,

- ułatwiają pracę, pomagają w planowaniu,

- umiejętności dla młodych w prowadzeniu działalności.

Do drugiej kategorii należeć będą takie odpowiedzi, jak:

- dadzą wymyślony przez urzędników papierek na to, co już umiem; nowy papierek i nic ponadto,

- umiejętności obsługi nowoczesnych maszyn, na które rolników nie stać,

- „sam chciałbym wiedzieć, co dają".

Osoby udzielające odpowiedzi dających się zaliczyć do dwóch wskazanych kategorii różniły się od siebie przede wszystkim pod względem wykształcenia oraz korzystania z pomocy UE. Respondenci wskazujący, że szkolenia dofinansowane z UE pozwalają na uzyskanie konkretnych informacji, kwalifikacji i umiejętności, to częściej osoby korzystające z pomocy UE. Częściej też niż respondenci, dla których szkolenia te nie przedstawiają większej wartości, są to osoby z wykształceniem wyższym i policealnym, podczas gdy ci drudzy częściej legitymują się wykształceniem podstawowym. Wśród respondentów uznających, że szkolenia dofinansowane ze środków UE nie dają nic konkretnego, znaleźli się też wszyscy respondenci, którzy stwierdzili, że wejście Polski do UE nie zmieniło nic w sytuacji wsi i rolników.

Powiązanie gospodarstw z rynkiem jest jednym z warunków, jakie zapewnić mogą osiąganie takiego poziomu dochodów, który pozwala na utrzymanie tych gospodarstw bądź na ich rozwój. Zapytano zatem respondentów również o to, czy znane są im takie szkolenia i kursy realizowane w ramach unijnego wsparcia, które uczą budować te powiązania bądź umacniać istniejące. Spośród osób, które udzieliły odpowiedzi na to pytanie, zdecydowana większość nie zna tego typu szkoleń. Spośród kilku wskazań na znajomość jedynie dwa faktycznie odnosiły się do szkoleń, które jako takie można potraktować (sprzedaż produkcji na rynku europejskim, przepisy i normy warunkujące możliwość sprzedaży na rynku poza Polską), natomiast pozostałe wskazania twierdzące wynikały z niezrozumienia treści pytania. Respondenci jako pomagające budować rolnikom powiązania z rynkiem wskazali bowiem szkolenia dotyczące wypełniania wniosków o wsparcie unijne, możliwości rozwoju pozarolniczej działalności gospodarczej oraz przekwalifikowywania się osób po 50 roku życia. 


\section{Zakończenie}

Wyniki zrealizowanych badań wskazują, że unijne instrumenty wsparcia, które w największym stopniu przekładają się na (pozytywną) ocenę poakcesyjnej sytuacji polskiego rolnictwa w opinii beneficjentów, to środki, które nie mają charakteru produktywistycznego, tj. nie znajdują przełożenia na gospodarcze ożywienie w sektorze. Jest to widoczne zwłaszcza w przypadku badania i analizy sytuacji gospodarstw małych i średnich, które korzystają przede wszystkim z dopłat bezpośrednich, nie traktując ich jednak jako wsparcia, o które trzeba specjalnie zabiegać, lecz jako automatyczny niejako wzrost dochodu związany z obecną sytuacją gospodarczą i polską obecnością w UE.

Dopłaty bezpośrednie są przeznaczane przede wszystkim na wydatki o charakterze konsumpcyjnym; nie służą potrzebom produkcyjnym gospodarstwa rolnego, lecz potrzebom konsumpcyjnym obsługującej je rodziny (zob. także Kisiel i in. 2011, s. 109). Zależność ta wyraźna jest zwłaszcza w mniejszych obszarowo gospodarstwach lub gospodarstwach ekonomicznie słabszych (zob. np. Biernat-Jarka i Byczek 2010, s. 78). Przez badanych rolników zostały one potraktowane jako jedna ze składowych rolniczego dochodu.

Środki otrzymywane przez badanych na modernizację są wydatkowane zgodnie z tym celem, co wynika przede wszystkim z restrykcyjnych przepisów dotyczących ich rozliczania.

Mimo że poza dopłatami bezpośrednimi istnieje możliwość pozyskania środków na inne działania (m.in. modernizację gospodarstwa), wielu rolników ma obawy przed korzystaniem z tych instrumentów. W bardzo niewielkim stopniu rolnicy korzystają ze szkoleń i doradztwa finansowanych ze środków UE. Mimo deklarowanej znajomości szkoleń współfinansowanych ze środków unijnych (ok. 70\% badanych), większość z nich (powyżej 50\%) nie potrafi nawet wskazać, czego te szkolenia dotyczą. Uprawnione zatem jest stwierdzenie, że w praktyce funkcjonowania małych i średnich gospodarstw rolnych wiele z instrumentów wsparcia jest nieobecne, wpływu innych zaś - poza dopłatami bezpośrednimi - w codziennym gospodarowaniu kierownicy tych gospodarstw zdają się nie dostrzegać (zob. także Kutkowska i in. 2015, s. 246-247).

10 lat obecności Polski w UE niewiele zmieniło w sytuacji ekonomicznej indywidualnych gospodarstw rolnych, zwłaszcza tych małych i średnich: nie zredefiniowało ich możliwości rozwojowych, nie przyspieszyło koncentracji, nie spowodowało też wypadania gospodarstw niskotowarowych. WPR nie stanowi jak na razie impulsu rozwojowego dla tych gospodarstw. Jak wskazuje I. Bukraba-Rylska (2014, s. 65-66) „Po dziesięciu latach obecności Polski w strukturach Unii Europejskiej wszelka jednoznaczna ocena akcesji wydaje się niemożliwa (...). Kwestię członkostwa Polski w UE postrzeganą przez pryzmat wsi i rolnictwa można sprowadzić do odpowiedzi na podstawowe pytanie: czy cele wiązane z członkostwem w Unii (restrukturyzacja i modernizacja sektora żywnościowego oraz rozwój obszarów wiejskich) udaje się osiągnąć? (...) Jeśli przywołane sformułowania (....) uznać za równoznaczne ze zwiększeniem potencjału polskiego rolnictwa, podniesieniem poziomu produkcji i wyrównywaniem różnic między wsią a miastem, to głębszy namysł nad dostępnymi danymi musi skłaniać do sceptycyzmu". Pamiętać jednak należy, że rolnictwo to sektor, w którym zmiany zachodzą bardzo wolno, trudno zatem dzisiaj jeszcze o kategoryczne stwierdzenia. Do tych uprawni być może bilans kolejnego dziesięciolecia. 


\section{Literatura}

10 lat członkostwa Polski w Unii Europejskiej, 2014, CBOS, Warszawa.

Biernat-Jarka A., Byczek A., 2010, Znaczenie płatności bezpośrednich w funkcjonowaniu wybranych gospodarstw województwa mazowieckiego, Zeszyty Naukowe SGGW - Ekonomika i Organizacja Gospodarki Żywnościowej, 86, s. 69-80.

Bułkowska M., Chmurzyńska K., 2007, Wyniki realizacji PROW i SPO "Rolnictwo" w latach 2004-2006, IERigż PAN, Warszawa.

Bukraba-Rylska I., 2014, Polska wieś w UE: esej o (brakujqcej) „Wielkiej Narracji”, Wieś i Rolnictwo, 2 (163), s. 65-81.

Fedyszak -Radziejowska B., 2012, Społeczności wiejskie: ewolucyjne zmiany, zrównoważony rozwój, [w:] J. Wilkin, I. Nurzyńska (red), Polska wieś 2012. Raport o stanie wsi, SCHOLAR, Warszawa, s. 101-124.

Halamska M., 2007, Rolnicy - Wspólna Polityka Rolna-Rozwój, Studia Regionalne i Lokalne, 2 (28), s. 5-12.

Hanusik K. Sokołowska S. 2005, Uwarunkowania podejmowania decyzji produkcyjnych w rolnictwie. Aspekt przestrzenny [w:] K. Hanusik, U. Łangowska-Szczęśniak, S. Sokołowska (red.), Przemiany społeczne, ekonomiczne i organizacyjne we współczesnej gospodarce polskiej, Wydawnictwo Uniwersytetu Opolskiego, Opole, s. 141-145.

Kisiel R., Marks-Bielska R., Kowalska A., 2011, Dopłaty bezpośrednie a zmiany w gospodarstwach rolnych na przykładzie wybranych powiatów województwa warmińsko-mazurskiego, Journal of Agribusiness and Rural Development, 4 (22), s. 101-114.

Krzyworzeka A., 2014, Rolnicze strategie pracy i przetrwania, Wydawnictwo Uniwersytetu Warszawskiego, Warszawa.

Kutkowska B., Berbeka T., Pilawka T., 2015, Wpływ instrumentów Wspólnej Polityki Rolnej na sytuację gospodarstw indywidualnych w opinii rolników, Roczniki Naukowe Stowarzyszenia Ekonomistów Rolnictwa i Agrobiznesu, 17 (3), s. 243-248.

Łopaciuk W., 2011, Wpływ Wspólnej Polityki Rolnej na rolnictwo, IERiGŻ, Warszawa.

Marks-Bielska R., 2009, Wsparcie dochodów rolników w formie dopłat bezpośrednich, Zeszyty Naukowe Ekonomika i Organizacja Gospodarki Żywnościowej, SGGW, Warszawa, s. 135-148.

Poczta W., 2012, Przemiany w rolnictwie ze szczególnym uwzględnieniem przemian strukturalnych, [w:] J. Wilkin, I. Nurzyńska (red.), Polska wieś 2012. Raport o stanie wsi, SCHOLAR, Warszawa, s. 65-99.

Poczta W., Hardt t., 2005, Skutki integracji Polski z UE dla rolnictwa i obszarów wiejskich. Próba oceny, [w:] Polska w UE. Doświadczenia pierwszego roku członkostwa, UKIE, Warszawa, s. 115-156.

Powszechny Spis Rolny 2002. Raport z wyników, 2003, GUS, Warszawa.

Powszechny Spis Rolny 2010. Raport z wyników, 2013, GUS, Warszawa.

Sokołowska S., Bisaga A., 2009, Wspólna Polityka Rolna jako przesłanka zarzqdzania zmianami w rolnictwie regionu opolskiego, [w:] P. Rostropowicz (red.), Województwo opolskie po wejściu do Unii Europejskiej - wymiar społeczno-ekonomiczny, Górnośląskie Centrum Kultury i Spotkań im. J. v. Eichendorffa w Łubowicach, Łubowice, s. 59-73.

Sokołowska S., Bisaga A., Szwiec P., 2006, Zmiany w organizacji i produktywności rolnictwa indywidualnego w procesie integracji z Uniq Europejskq (na przykładzie badan w województwie opolskim), Wyd. Uniwersytetu Opolskiego, Opole.

Sokołowska S., Szwiec P. 2011, Postrzeganie polityki rolnej prowadzonej w Polsce w kontekście WPR Unii Europejskiej przez kierowników indywidualnych gospodarstw rolnych, Wieś i Rolnictwo, 3 (152), s. 127-137.

Zegar J., 2009, Kwestia koncentracji ziemi w polskim rolnictwie indywidualnym, Roczniki Nauk Rolniczych, Seria G, 96, 4, s. 256-266. 


\section{Summary}

The aim of this article is to assess the impact of the Common Agricultural Policy instruments on individual farms in the Opolskie Voivodship. The research was based on a survey conducted among farmers. The objective was to determine the socio-economic transformation, which in the opinion of farmers occurred in rural areas of the Opolskie Voivodship after Poland's accession to the European Union. The survey embraced 383 individual farmstead managers with farm size ranging from 2 to 30 ha. The results show i.a. the impact of EU regulations on farmers' situation, but also their attitude towards them. Farmers appreciate the EU support, however they are mostly focused on direct payments and the related increase in income. They rarely take advantage from other forms of support, for example training and consulting. Moreover, farm owners not often apply for modernization funds for farmsteads, especially if case of small sized farms. 
http://rcin.org.pl 